Original Paper

\title{
Penerapan Pembelajaran Kooperatif Tipe Inside Outside Circle (IOC) untuk Meningkatkan Hasi Belajar Siswa
}

\author{
Ni Wayan Sri Kastining ${ }^{\text {* }}$ \\ ${ }^{1}$ Sekolah Menengah Atas Negeri 1 Mataram, Indonesia.
}

*Corresponding Author: Ni Wayan Sri Kastining, Sekolah Menengah Atas Negeri 1 Mataram, Indonesia;

Email: srikastining30@gmail.com

\begin{abstract}
Abstrak: Tujuan penelitian tindakan kelas ini adalah untuk meningkatkan hasil belajar Sejarah siswa kelas X IPS 1 SMA Negeri 1 Mataram pada materi sumber sejarah dan tahapan penelitian sejarah dengan menerapkan pembelajaran Kooperatif tife Insede Outside Circle (IOC). Penerapan pembelajaran Kooperatif tife Insede Outside Circle (IOC) ini diharapkan dapat memperbaiki proses pembelajaran sehingga hasil belajar siswa menjadi meningkat. Penelitian ini dilaksanakan dalam 2 (dua siklus). Setiap siklus terdiri dari perencanaan, pelaksanaan, observasi dan refleksi. Pelaksanaan siklis I dari tanggalan 2 Agustus 2018 sampai 16 Agustus 2018 dan siklus II dari tanggal 23 Agustus 2018 sampai 6 September 2018. Berdasarkan hasil penelitian, diperoleh hasil belajar siswa pada siklus I sebesar $51 \%$ siswa mendapat nilai $\geq 75$ Karena pada siklus I belum memenuhi ketuntasan belaja yang diisyaratkan yaitu $85 \%$ siswa mendapatkan nilai $\geq 7,5$, maka penelitian dilanjutkan ke siklus II. Hasil yang diperoleh pada siklus II, sebesar $93 \%$ yang artinya ketuntasan belajar sudah tercapai dan hasil belajar mengalami peningkatan, disimpulkan dengan penerapan pembelajaran Kooperatif tife Insede Outside Circle (IOC) dapat meningkatkan hasill belajar siswa kelas X IPS 1 SMA Negeri 1 Mataram tahun pelajaran 2018/2019 pada mata pelajaran sejarah.
\end{abstract}

Kata Kunci: Pembelajaran Kooperatif; Insede Outside Circle (IOC); Peningkatan hasil belajar; Sumber sejarah dan Tahapan penelitian sejarah.

\section{Pendahuluan}

Kemajuan suatu bangsa sangat ditentukan oleh kualitas Sumber Daya Manusia (SDM) dan karenanya pendidikan mempunyai peranan yang sangat strategis dalam pengembangan SDM yang berkualitas agar memiliki pengetahuan, keterampilan, kreatif dan inovatif seiring dengan kemajuan ilmu pengetahuan dan teknologi. Salah satu pendukung terlaksananya pendidikan dalam proses pembelajaran adalah adanya guru sebagai unsur pembimbing dalam proses belajar mengajar.

Dalam undang-undang No.20 tahun 2003 pasal 1 disebutkan bahwa pendidikan adalah usaha sadar dan terencana untuk mewujudkan suasana belajar dalam proses pembelajaran agar peserta didik secara aktif mengembangkan potensi dirinya untuk memiliki kekuatan spiritual keagamaan, pengendalian diri, kepribadian, kecerdasan dan akhlak mulia serta keterampilan yang diperlukan dirinya, masyarakat, bangsa dan Negara.

Salah satu kemampuan yang harus dimiliki guru sebagai pendidik, guru harus mampu melaksanakan tugas profesionalnya yaitu memahami bagaimana mengorganisasikan proses pembelajaran yang mampu mengembangkan kemampuan siswa serta meningkatkan keaktifan dan prestasi belajar siswa. Sebagai bagian dari proses pendidikan, guru memiliki peranan dan tanggung jawab yang sangat besar dalam pencapaian tujuan pembelajaran.

Untuk mencapai tujuan tersebut banyak upaya yang telah dilakukan, termasuk di dalamnya pengembangan inovasi pembelajaran dan penyempurnaan belajar. Namun upaya tersebut belum menunjukkan hasil yang maksimal terutama pada bidang studi Sejarah di SMA Negeri 1 Mataram, dimana diproleh hasil belajar siswa yang kurang memuaskan. Hasil belajar terutama di kelas $\mathrm{X}$ IPS 1 SMA Negeri 1 Mataram masih rendah, 
dalam artian belum mencapai target ketuntasan sebagaimana ditetapkan oleh standar pendidikan nasional, yaitu hasil pembelajaran dikatakan tuntas secara individu jika masing-masing siswa dapat mencapai KKM 75, dan secara klasikal, apabila lebih dari atau sama dengan $85 \%$ siswa memproleh nilai sama dengan atau lebih dari standar ketuntasan. Hal ini dapat dilihat dari perolehan nilai pada KD 3.2 siswa kelas X IPS 1 pada tahun pelajaran 2018/2019.

Untuk mengatasi permasalahan tersebut peneliti mencoba menerapkan model pembelajaran yang bisa mengoptimalkan kegiatan siswa, mendorong siswa untuk aktif, bertanya dan berdiskusi dalam kegiatan belajar mengajar. Salah satu model pembelajaran yang dapat mengaktifkan siswa adalah model pembelajaran kooperatif tipe Inside Outside Circle (IOC). Model pembelajaran kooperatif tipe Inside Outside Circle (IOC) merupakan model pembelajaran dimana sebagian siswa akan membentuk lingkaran kecil dan sebagian lagi membentuk lingkaran besar. Siswa pada lingkaran kecil akan saling berhadapan dengan siswa pada lingkaran besar. Siswa yang saling berhadapan ini akan saling bertukar informasi, kemudian siswa pada lingkaran besar akan bergeser satu atau dua langkah searah jarum jam.

Dengan cara ini, masing-masing siswa mendapatkan pasangan baru untuk berdiskusi atau bertukar informasi. Salah satu keunggulan teknik ini adalah adanya struktur yang jelas dan memungkinkan siswa untuk berbagi informasi dengan pasangan yang berbeda dengan singkat dan teratur. Selain itu, siswa bekerja dengan sesama siswa dalam suasana gotong royong dan mempunyai banyak kesempatan untuk mengolah informasi dan meningkatkan keterampilan berkomunikasi (Lie, 2008:65). Oleh karena itu peneliti bermaksud mengadakan penelitian dengan judul "Penerapan model pembelajaran kooperatif tipe Inside Outside Circle untuk meningkatkan prestasi belajar siswa kelas X IPS 1 SMA Negeri 1 Mataram pada mata pelajaran sejarah Tahun Pelajaran 2018/2019".

\section{Metode}

Jenis penelitian yang digunakan adalah penelitian Tindakan kelas. Penilitian Tindakan kelas adalah penelitian yang dilakukan guru atau peneliti di dalam kelas, dengan tujuan untuk memperbaiki kinerja guru sehingga hasil belajar siswa menjadi meningkat (Wardani, 2003). Karena permasalahan yang dihadapi dan diamati oleh guru maka solusinya dirancang berdasarkan kajian teori pembelajaran dan input dari lapangan. Disamping itu pelaksanaan tindakan juga dilakukan oleh guru sebagai observer dan peneliti sebagai pengajar.

Pendekatan yang digunakan dalam penelitian ini adalah: 1) Kualitatif yaitu pendekatan dengan pengambilan data yang berupa kategorisasi, karakteristik atau bersifat variabel (Corbin, dkk: 2003). 2) Kuantitatif yaitu pendekatan dengan pengambilan data yang berupa data statistik atau berupa angka-angka yang diolah menjadi sebuah informasi (Kuncoro, 2007). Penelitian ini dilaksanakan bertempat di SMA Negeri 1 Mataram. Adapun subyek penelitian ini adalah siswa kelas X IPS 1 semester ganjil tahun pelajaran 2018/2019. Dengan banyak siswa 41 orang laki-laki dan perempuan

Teknik pengumpulan data adalah suatu usaha dasar untuk mengumpulkan data yang dilakukan secara sistematis dan terstandar (Arikunto, 2008). Sumber data adalah sumber primer dengan memberikan kusioner (angket) kepada responden. Metode pengumpulan data yang dipakai dalam penelitian ini ada dua: 1) Observasi diartikan sebagai pengamatan dan pencatatan secara sistematik terhadap gejala yang tampak terhadap objek penelitian. Pengamatan dan pencatatan ini dilakukan terhadap objek di tempat berlangsungnya peristiwa (Margono, 2003). Dalam penelitian ini, observasi digunakan untuk memproleh data aktivitas siswa dan kegiatan guru pada saat proses belajar mengajar berlangsung. 2) Tes adalah seperangkat rangsangan (stimulus) yang diberikan kepada seseorang dengan maksud untuk mendapat jawaban yang dijadikan dasar bagi penetapan skor angka (Margono, 2003).

Tes dilakukan untuk mengetahui sejauh mana pemahaman siswa terhadap pelajaran yang diberikan dengan menggunakan model pembelajaran kooperatif teknik Inside Outside Circle selama proses pembelajaran

Data aktivitas belajar siswa dianalisis dengan cara deskriptif kualitatif dengan menggunakan skor 0 dan 1. Skor 1 diberikan jika deskriptor nampak dan skor 0 jika tidak nampak, jumlah yang diamati 
adalah 6 indikator dan setiap indikator terdiri dari 4 deskriptor.

Setiap indikator prilaku guru pada penelitian ini, penilainnya berdasarkan kriteria sebagai berikut: 1) Skor 4 diberikan jika 3 (semua) deskriptor yang nampak. 2) Skor 3 diberikan jika 2 deskriptor yang nampak. 3) Skor 2 diberikan jika 1 deskriptor yang nampak. Dan 4) Skor 1 diberikan jika tidak ada deskriptor yang nampak.

Untuk mengetahui prestasi belajar siswa, hasil tes belajar dianalisis secara deskriptif yaitu dengan menentukan rata-rata nilai hasil tes. Penentuan nilai sebagai standar sebesar 75 . Penentuan nilai ini berdasarkan pada kriteria ketuntasan minimal (KKM) yang ditetapkan sekolah yang bersangkutan. Adapun berdasarkan kurikulum, ketuntasan tercapai jika $\mathrm{KB} \geq 85 \%$. (Depdikbud, 1994:2)

Apabila masih terjadi kesulitan pemahaman materi tertentu pada satu siklus, maka untuk mengatasi materi yang dirasakan sulit oleh siswa tersebut akan lebih ditekankan kembali pada kegiatan pendahuluan pembelajaran siklus berikutnya

\section{Hasil dan Pembahasan}

\section{Siklus I}

Proses belajar mengajar pada siklus I dilaksanakan 3 (tiga) kali pertemuan. Dimana pada proses belajar mengajar pada pertemuan pertama dikatagorikan cukup baik. Akan tetapi, di dalam proses belajar mengajar masih banyak terdapat siswa yang kurang antusias dalam melaksanakan kegiatan diskusi. Hal ini disebabkan karena kurang mendapatkan motivasi sehingga proses belajar mengajar tidak berjalan dengan lancar. Perhatian atau antusias mempunyai peranan penting dalam kegiatan belajar. Dari kajian teori belajar pengolahan informasi terungkap bahwa tanpa adanya perhatian tak mungkin terjadi belajar. (Gage dan Berliner, 1984:335). Perhatian terhadap pelajaran akan timbul pada siswa apabila bahan pelajaran sesuai dengan kebutuhannya. Apabila bahan pelajaran itu dirasakan sebagai suatu yang dibutuhkan atau diperlukan dalam kehidupan sehari-hari, akan mengakibatkan motivasi untuk mempelajarinya (Dimyati dan Mudjiono, 2002:42).

Proses belajar mengajar pada pertemuan kedua sudah mulai berjalan sedikit lebih baik dari pertemuan pertama, dimana masih ada beberapa orang siswa yang masih kurang berparti sifasi aktif. Hal ini disebabkan karena kurangnya aktivitas siswa dalam diskusi kelompok, dimana siswa tersebut hanya diam saja, tidak mengajukan pendapatnya dan tidak melakukan diskusi dengan baik. Untuk itu guru harus lebih memberikan motivasi kepada siswa tersebut dengan menyampaikan bahwa melalui diskusi akan mempermudah dalam memahami konsep, sehingga dapat menyelesaikan soal yang berkaitan dengan konsep yang di pelajari. Seperti yang diungkapkan oleh John Dewey dalam (Dimyati dan Mudjiono, 2002:42) mengemukakan bahwa belajar adalah menyangkut apa yang harus dikerjakan siswa untuk dirinya sendiri, maka inisiatif harus datang dari siswa sendiri. (Gagne and berliner, 1984:267) dalam (Dimyati dan Mudjiono, 2002:45) juga mengemukakan bahwa anak memiliki sifat aktif, konstuktif, dan mampu merencanakan sesuatu. Anak mampu untuk mencari, menemukan dan menggunakan pengetahuan yang telah diperolehnya. Dalam proses belajar mengajar anak mampu mengidentifikasi, merumuskan masalah, mencari dan menemukan fakta, menganalisis, menafsirkan dan menarik kesimpulan.

Hasil observasi siswa pada siklus I berdasarkan tabel 4.1 dapat terlihat secara klasikal Rata-rata kendala siswa menjadi kurang aktif dikelas karena siswa tersebut tidak terlalu aktif dalam diskusi kelompoknya, sehingga mempengaruhi hasil belajarnya. Ada juga bebarapa siswa yang masih kesulitan dalam membuat kesimpulan akhir pada proses pembelajarannya. Ada juga beberapa siswa yang tidak terlalu memberikan respon atas stimulus yang diberikan oleh teman dan gurunya. Namun pada pertemuan berikutnya setelah dilakukan perbaikan-perbaikan dari kendala yang terjadi pada pertemuan I, maka pada pertemuan kedua aktivitas belajar siswa menjadi meningkat. Walaupun aktivitas belajar siswa sudah mengalami peningkatan namun masih ada beberapa siswa ini masih kurang serius dalam melakukan diskusi, siswa tersebut tidak mengajukan pendapat baik dalam diskusi kelompok maupun saat membuat kesimpulan. Disamping itu perhatiannya masih kurang saat pembelajaran berlangsung. Dari data ini meski sudah ditunjukkan keaktifan siswa ada, namun masih banyak perbaikan yang harus dilakukan selama proses pembelajaran berlangsung. 
Berdasarkan hasil observasi aktivitas mengajar guru pada siklus I, terdapat beberapa deskriptor yang tidak nampak. Akan tetapi setelah dilakukan penyempurnaan dan perbaikan pada pertemuan berikutnya terhadap deskriptor yang tidak nampak, maka kegiatan aktivitas mengajar guru dapat dikatagorikan baik.

Pada pertemuan ketiga dilakukan evaluasi yang dilaksanakan pada tanggal 16 Agustus 2018 dengan alokasi waktu $2 \times 45$ menit. Dari tabel 4.4, hasil evaluasi menunjukkan bahwa nilai rata-rata dari 41 orang siswa yang mengikuti tes evaluasi memperoleh nilai rata-rata 71 dengan persentase ketuntasan belajar siswa mencapai $51 \%$. Sedangkan ketuntasan klaksikal dikatakan tuntas apabila > $85 \%$. Jadi, dapat disimpulkan bahwa hasil ketuntasan pada siklus I belum tuntas. Oleh karena itu, peneliti ingin meningkatkan ketuntasan klaksikal dengan melanjutkan ke siklus selanjutnya. Namun sebelumnya dilaksanakan refleksi ataupun perbaikan perbaikan terhadap kekurangan yang ada pada siklus I. Adapun perbaikan-perbaikan yang harus dilakukan guru selain dari perbaikanperbaikan yang disebutkan dilembar perbaikan kegiatan guru diatas adalah sebagai berikut: 1) Guru berusaha membuat suasana belajar yang menyenangkan sehingga siswa merasa nyaman dan senang belajar. 2) Guru memotivasi siswa untuk mengerjakan tugas sesuai tugas dari kelompok masing-masing dengan cara tiap kelompok yang bekerjasama dengan baik akan mendapat nilai tambahan. 3) Guru harus lebih membimbing siswa dalam membuat kesimpulan. 4) Guru harus bisa menguasai kelas dengan baik agar proses belajar dapat berjalan dengan lancar. 5) Guru sebaiknya menjelaskan kembali soal evaluasi yang dianggap sulit.

\section{Siklus II}

Proses belajar mengajar pada siklus II dilaksanakan 3 (tiga) kali pertemuan. Dimana proses belajar mengajar pada pertemuan pertama ini berjalan efektif meskipun masih ada siswa yang masih dikatagorikan kurang aktif. Hal ini disebabkan karena masih kurangnya aktivitas siswa dalam diskusi kelompok, dimana siswa tersebut masih tetap diam saja seperti pada pertemuan sebelumnya. Untuk itu guru harus melakukan pendekatan-pendekatan kepada siswa tersebut dengan memberikan motivasi yang lebih intensif sehingga siswa tersebut dapat melakukan diskusi dengan baik.

Pada pertemuan kedua yang alokasi waktunya 2x45 menit dilakukan evaluasi materi yang sudah diajarkan pada pertemuan pertama. Proses belajar mengajar pada pertemuan kedua ini berjalan dengan sangat aktif sesuai dengan rencana pelaksanaan pembelajaran yaitu telah menunjukkan kesesuaian antara tindakan yang diinginkan peneliti karena pembelajaran tersebut telah mencerminkan kegiatan pembelajaran yang sangat aktif dalam diskusi serta tidak ada lagi yang kita temukan siswa yang dikatagorikan sangat kurang aktif.

\section{Hasil observasi siswa pada siklus II}

Pada siklus II setelah dikukan perbaikanperbaikan dari pertemuan pemelajaran sebelumnya,dan setelah dilakukan perbaikanperbaikan dari kendala yang terjadi pada pertemuan I, maka pada pertemuan kedua aktivitas belajar siswa menjadi meningkat.

Kegiatan guru pada siklus II sudah disempurnakan dari kekurangan terhadap indikator yang tidak nampak pada siklus I. Berdasarkan hasil observasi, guru telah melakukan kegiatan dengan baik dan sesuai dengan rencana pelaksanaan pembelajaran yang telah disusun.

Pada pertemuan kedua dilakukan evaluasi dimana hasilnya dapat dilihat pada tabel 4.7 , hasil evaluasi menunjukkan bahwa nilai rata-rata dari 41 orang siswa yang mengikuti tes evaluasi memperoleh nilai rata-rata 84 dengan persentase ketuntasan belajar siswa mencapai $93 \%$. Oleh karena itu dapat disimpulkan bahwa ketuntasan secara klaksikal telah tercapai karena ketuntasan belajar siswa telah mencapai > 85\%. Hal ini disebabkan karena pada siklus II siswa lebih antusias dan termotivasi dalam menerima pelajaran yang diberikan oleh guru.

Berdasarkan hasil analisis data yang diperoleh bahwa dalam pembelajaran kooperatif tipe Inside Outside Circle dapat meningkatkan prestasi belajar siswa. Persentase ketuntasan belajar pada siklus I adalah 51\% mengalarni peningkatan menjadi $93 \%$ pada siklus II. Adanya peningkatan ketuntasan belajar siswa mulai dari siklus I dan siklus II karena penerapan model pembelajaran kooperatif tipe Inside Outside Circle. Pembelajaran kooperatif dapat meningkatkan pemahaman siswa tentang materi yang diajarkan. Keuntungan dari kerja kelompok salah satunya dalah siswa lebih 
aktif tergabung dalam pembelajaran dan mereka lebih aktif berpartisipasi dalam diskusi

\section{Kesimpulan}

Berdasakan analisis data dan pembahasan hasil penelitian, disimpulkan bahwa penerapan model pembelajaran kooperatif tipe Inside Outside Circle dapat meningkatkan Prestasi belajar siswa kelas X IPS 1 SMA Negeri 1 Mataram Tahun Pelajaran 2018/2019. Hal ini dapat dilihas dari ketuntasan klasikal yang di peroleh pada evaluasi siswa siklus I dengan nilai rata-rata sebesar 71 dengan ketercapaian hasil belajar siswa sebesar 51 $\%$. Sedangkan hasil ketuntasan klasikal yang diperoleh pada evaluasi siswa siklus II dengan nilai rata-rata sebesar 83 dengan ketercapaian hasil belajar siswa sebesar 93\%. Hal ini menunjukan adanya peningkatan prestasi belajar siswa.

\section{Daftar Pustaka}

Arikunto, S. 2008. Prosedur Penelitian, Suatu Pendekatan Praktek. Yogyakarta: Rineka Cipta

Berliner \& Gage. 1984. Educational Psychology. 3rd edition. Houghton Mifflin Company. All right reserved.

Corbin, J \& Strauss, A. 2003. Dasar-Dasar Penelitian Kualitatif: Tatalangkah dan Tekni-teknik Teorisasi Data. Yogyakarta: Pustaka Pelajar.

Depdikbud. 1992. Strategi Belajar Mengajar. Jakarta : Univeristas Terbuka

Dimyati \& Mudjiono. 2002. Belajar dan Pembelajaran. Jakarta: Rineka Cipta

Kuncoro, M. 2007. Metode Kuantitatif: Teori dan Aplikasi Untuk Bisnis dan Ekonomi. Yogyakarta: UPP STIM YKPN.

Lie, A. 2008. Cooperative Learning: Mempraktikkan Cooperative Learning di Ruang-ruang Kelas. Jakarta: PT Grasindo

Margono. 2003. Metode Penelitian Pendidikan. Jakarta: PT Asdi Mahasatya

Wardani. 2003. Penelitian Tindakan Kelas. Jakarta: Universitas Terbuka Departemen Pendidikan Nasional 